desde la academia | dossier

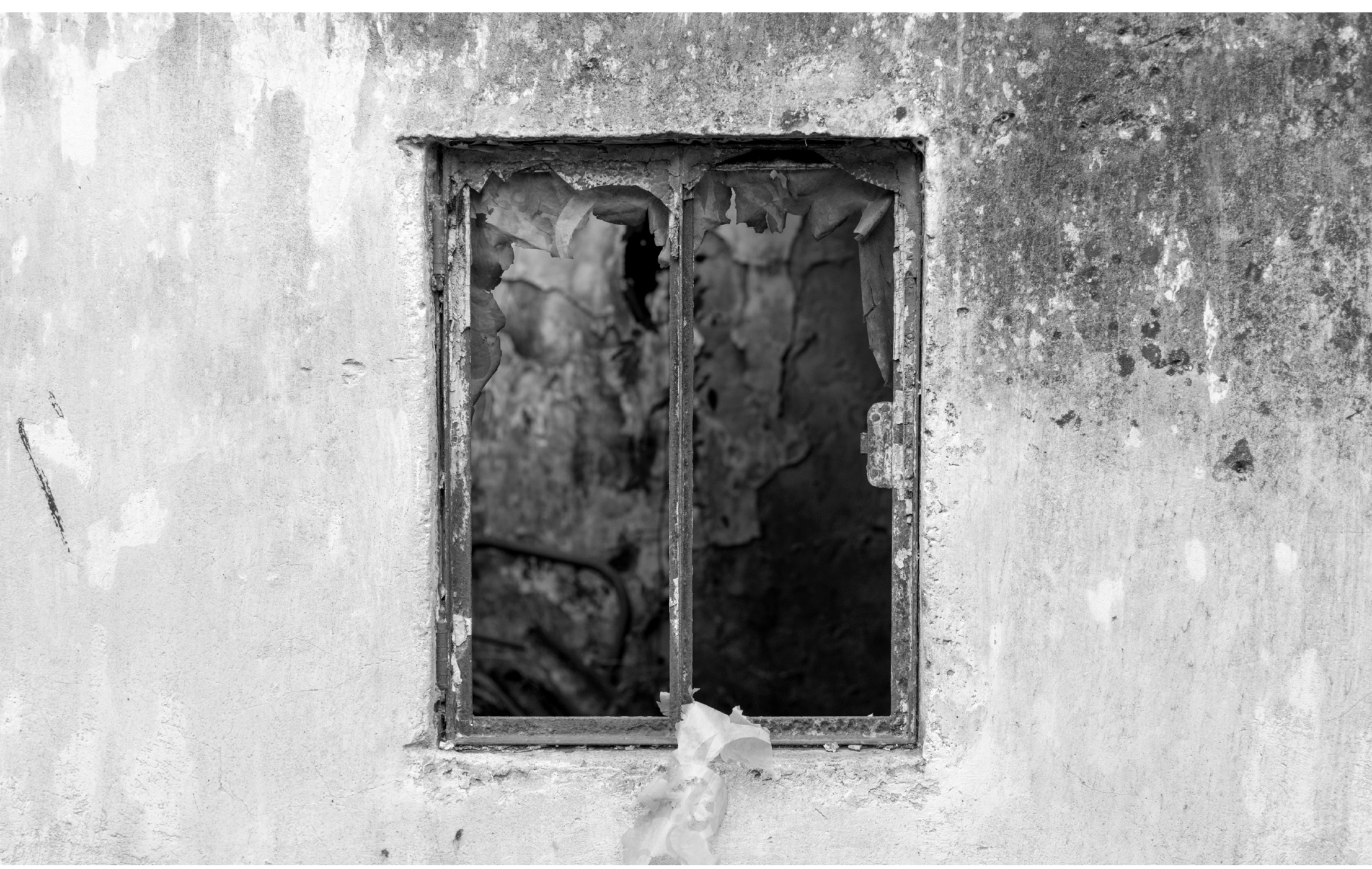

\title{
Por causa de uma cerca: Território e narrativa cisados pelo medo em O som ao redor e Historia del miedo
}

Por una cerca: Territorio y narrativa divididos por el miedo en $\mathrm{O}$ som ao redor e Historia del miedo Due to a fence: Territorie and narrative split by fear in the movies $\mathrm{O}$ som ao redor and Historia del miedo

DOI: https://doi.org/10.22235/d.vi31.1868

Fernanda Sales Rocha Santos 
RESUMO

Será realizada uma análise comparativa entre o longa-metragem brasileiro 0 som ao redor (Kleber Mendonça Filho, 2013) e o filme argentino Historia del miedo (Benjamín Naishtat, 2014) por meio do estudo de como a temática da cisão territorial -tanto na Grande Buenos Aires, quanto em Recife- se relaciona com a questão do ressentimento social e se reflete, de forma análoga, na estrutura narrativa e estética de ambos os filmes. Para tanto, será demonstrado como a fragmentação narrativa, em diálogo com elementos de uma tradição do horror, se vincula com a temática do ressentimento por motivos territoriais nos dois países. Diante das urgências das disputas pelo espaço que tanto o filme de Benjamín Naishtat quanto o de Kleber Mendonça Filho evocam, busca-se comparar os recursos narrativos para a abordagem de um impasse ancestral e central da América Latina: o impasse das cercas.

Palavras-chave: cinema brasileiro; cinema argentino; fragmentação narrativa; horror; ressentimento social.

\section{RESUMEN}

Se hará un análisis comparativo entre el largometraje brasileño 0 som ao redor (Kleber Mendonça Filho, 2013) y la película argentina Historia del miedo (Benjamín Naishtat, 2014). Este análisis tendrá en cuenta cómo el tema de la división territorial -tanto en Recife como en Buenos Aires- se relaciona con el tema del resentimiento social y se refleja en la estructura narrativa y estética de ambas películas. Para ello, se demostrará cómo la fragmentación narrativa, en diálogo con elementos de una tradición de horror, está ligada a temáticas de resentimiento por razones territoriales en ambos países. Dada la urgencia de las disputas por el espacio que evocan tanto la película de Benjamín Naishtat como la de Kleber Mendonça Filho, buscamos comparar recursos narrativos para el enfoque de un antiguo y central impasse en América Latina: el impasse de las cercas. Palabras clave: cine brasileño; cine argentino; fragmentación narrativa; horror; resentimiento social.

\section{ABSTRACT}

We will make a comparative analysis between the Brazilian film 0 som ao redor (KleberMendonça Filho, 2013) and the Argentine film Historia del miedo (Benjamín Naishtat, 2014). This analysis will take into account the study of how the issue of territorial split -both in Recife and Buenos Aires - relates to the issue of social resentment and is reflected in the narrative and aesthetic structure in both films. To this end, it will be demonstrated how narrative fragmentation, in dialogue with elements of a horror tradition, is linked to thematic issues of resentment for territorial reasons in both countries. Given the urgency of the disputes for space that both Benjamin Naishtat's film and Kleber Mendonça Filho's film evoke, we seek to compare narrative resources for the approach of an ancient and central impasse in Latin America: the fence impasse.

Keywords: Brazilian cinema; Argentine cinema; narrative fragmentation; horror; social resentment.

El miedo ao redor: Introduzindo dois filmes 0 filme brasileiro $O$ som ao redor (Kleber Mendonça Filho, 2013) e o argentino Historia del miedo (Benjamín Naishtat, 2014) são obras que, além de lançarem mão de procedimentos estéticos semelhantes, possuem enredos e motivos temáticos similares. Ambos abordam a questão da (in)segurança no espaço urbano, tratando de assuntos como a vida cotidiana em condomínios fechados, com seus vigias, alarmes, cães e, principalmente, com a contínua ameaça do corpo estranho, historicamente excluído e ressentido socialmente. A atmosfera sensória de medo que permeia a experiência quotidiana dos habitantes dos centros urbanos do Brasil e da Argentina é articulada, estética e narrativamente, a partir de uma combinação de elementos de um realismo social e sensório contemporâneo com procedimentos do cinema de gênero, particularmente do horror. ${ }^{1}$ Ambos os filmes se organizam sobre uma narrativa fragmentada com diversos núcleos de ação, lançando uma espécie de olhar panorâmico e sociológico sobre as relações de poder e convivência em um ambiente determinado - no caso de $O$ som ao redor, uma rua de classe-média alta na cidade de Recife; no caso de Historia del miedo, os arredores de um condomínio horizontal localizado no partido de Moreno, na região metropolitana da Grande Buenos Aires-.
Fernanda Sales

Rocha Santos Universidade de São Paulo (USP), São Paulo, Brasil https://orcid.org/00000002-0822-440X fer.salesrocha@usp.br

Recepción: 16/09/2019 Aceptación: 26/10/2019

\begin{abstract}
1:: Para um
aprofundamento sobre a relação entre o realismo sensório e horror nesses dois longas-metragens ver Sales Rocha Santos (2018).
\end{abstract}


2:: Segundo Luís Mendonça (2015), em texto que introduz entrevista com Mendonça Filho sobre seus curtas: "[A relação] começa com Enjaulado (1997), um primeiro filme sobre 'paranoia da classe média', que podia ser uma das histórias de $O$ som ao redor. Em A menina do algodão (2003) temos uma história de assombração na escola João Carpinteiro. Escola com o mesmo nome aparece

em $O$ som ao redor, numa homenagem mais ou menos escondida a John Carpenter. Eletrodoméstica (2005) é como que refeito numa das histórias de $O$ som ao redor. Em Recife frio (2009) o narrador diz, a certa altura: '(...) Recife já sofria do medo paralisante da violência e a fealdade do urbanismo agressivo tão comum em cidades latinoamericanas. 0 espaço urbano

caótico, piorado por uma especulação imobiliária fora de controle abria espaço para a desumanização das cidades'. Quando chegamos a 0 som ao redor também estas palavras estão lá transformadas num thriller social muito subtil".

3:: Segundo Kleber Mendonça

Filho: "Eu cresci nos anos 1980, vendo filmes dos anos $1980 \mathrm{e}$ 1970 (...). Então, basicamente, eu fiz uma história totalmente brasileira, mas usando uma câmara talvez dos americanos dos anos 1970. 0 filme tem alguns aspectos do cinema americano clássico: tela larga, wide shots, $35 \mathrm{~mm}$ (...) 0 som ao redor passa-se em lugares

muito normais: cozinhas, salas, corredores, rua. Nada

é espetacular, tudo é muito comum. (...) 0 Brian De Palma numa cozinha brasileira numa terça-feira é mais interessante

do que filmar como na

televisão, que é aquilo que infelizmente vejo mais" (em entrevista a Mendonça, 2015). 4:: Sobre a semelhança entre ambos os longas, ver Ferreira (2014) e Calil (2015).
Primeiro longa-metragem ficcional de Kleber Mendonça Filho (crítico, curta-metragista, programador e curador de cinema), $O$ som ao redor culmina em um bem-sucedido acúmulo temático e formal dos curtas do próprio realizador, ${ }^{2}$ esbarrando em conteúdos frequentemente presentes na filmografia de outros cineastas brasileiros contemporâneos, como Sérgio Bianchi, Beto Brant e da dupla Juliana Rojas e Marco Dutra. Desses realizadores, o longa pernambucano toma um apreço pela observação do cotidiano de uma classe média e alta tipicamente brasileiras, além de uma narrativa na qual o vínculo das rotinas ordinárias das personagens é permeado pela tensão e pelo medo. Ao mesmo tempo, são evidentes as referências que 0 som ao redor faz a gêneros como o western e o horror. Neste ponto, Kleber Mendonça Filho enaltece o cinema americano dos anos 1970 e 1980, com ênfase à filmografia de John Carpenter, Brian De Palma e Spike Lee, sendo manifesto em suas obras o uso de procedimentos estilísticos recorrentes na filmografia destes realizadores. ${ }^{3}$

Estruturalmente, $O$ som ao redor é dividido em três partes: "Cães de guarda", "Guardas noturnos" e "Guarda-costas". Desenvolvendo-se como um multiplot que foca no dia a dia dos moradores de uma mesma rua no Recife, o longa exibe problemas corriqueiros que envolvem a segurança da rua, incômodos entre vizinhos e as relações - permeadas pelo suspense- entre funcionários, empregados e patrões. Um desses "fragmentos da vizinhança em sua rotina ordinária e amedrontada" ganha força ao final do longa, quando se revela um processo de vingança, um acerto de contas do passado relacionado à "história" de uma cerca. Assim, esse fragmento desvincula-se de uma narrativa interessada pelos gestos e costumes cotidianos, e se eleva com força dramatúrgica, conjuntamente a uma visão crítica sobre as relações históricas e de classe no Brasil. Contudo, esse processo de vingança não é óbvio, pois não se revela em sua potencialidade - ao espectador só é possível induzir o gesto de violência da vingança.

Projetando agressões ainda menos explícitas, no entanto não menos violentas, Historia del miedo (distribuído, no Brasil, com o título Bem perto de Buenos Aires), primeiro longa ficcional de Benjamín Naishtat, jovem realizador graduado na Universidad del Cine, é impregnado por fontes conceituais e estéticas semelhantes às de 0 som ao redor. ${ }^{4}$ Com uma estrutura que alterna o ponto de vista do jovem periférico Pola, e de personagens que vivem -amedrontadas-dentro da redoma de um condomínio horizontal fechado, o longa-metragem de Naishtat progride diante de uma fragmentação narrativa multiplot, observando relações cotidianas, especialmente entre patrões e empregados domésticos. Diferente do filme brasileiro, no caso de Historia del miedo não há um fragmento que se destaque dramaturgicamente a ponto de amarrar os indícios de amedrontamento das personagens. 0 enredo de Historia del miedo se desenvolve a partir da correlação entre três espaços: a periferia pobre, a periferia rica e o centro da cidade de Buenos Aires. A partir do momento em que as cercas que rodeiam um condomínio horizontal de luxo começam a surgir rompidas, com lixo espalhado em seu entorno e fogo posto em seus limites - atos relacionados a um assentamento nas redondezas do condomínio-, a atmosfera de insegurança se instaura e dá o tom ao filme. 0 tensionamento fundamental da narrativa do filme de Naishtat localiza-se nos limites entre uma periferia rica e outra pobre.

Naishtat, assim como Mendonça Filho, assume a influência direta da cinematografia do gênero de horror, citando especificamente os americanos John Carpenter e Tobe Hooper. Ele também indica que, para a criação da densa atmosfera de seu longa, é inspirado por sua conterrânea Lucrecia Martel, entre outros cineastas referenciais do realismo sensório 
contemporâneo. ${ }^{5}$ Relação direta com o cinema de gênero, temáticas sociais, olhar interessado em relações cotidianas, busca de uma atmosfera de tensão, fazem de $O$ som ao redor e de Historia del miedo experiências fílmicas paralelas. 0 depoimento a seguir, de Benjamín Naishtat, poderia também ser um depoimento de Kleber Mendonça Filho: "É um filme que tem um pouco a estrutura de thriller, mas com um fundo social forte, onde há a história de gente que vive em um bairro privado (...). E, bem, essas histórias são cruzadas e vão crescendo em tensão até o final" (Naishtat em entrevista a enelset CINE, 2014).

$\mathrm{Na}$ entrevista acima, o cineasta argentino ainda ressalta que o título original da película -Historia del miedo- é um jogo com a palavra história, que remete tanto ao enredo do filme, quanto à História da Argentina. Assim, o movimento narrativo de focar uma trama de relações costumeiras e cotidianas para se alcançar, de modo sutil, algo mais amplo, ou profundo, como a História de um país, é outro aspecto paralelo a $O$ som ao redor (principalmente com sua eloquente abertura composta por fotografias que fazem referência à estrutura colonial e arcaica das relações de trabalho no campo).

Conectados com questões importantes do espaço e do tempo histórico ao qual pertencem, os filmes de Mendonça Filho e Naishtat montam quadros realistas de histórias do medo em seus países. Nesses quadros, as cidades são territórios de disputa e, também por isso, de insegurança. Por trás de cercas, grades e muros, nenhum espaço convida ao bem-estar ou à sociabilidade, pelo contrário: esses ambientes privados adensam a sensação do isolamento e do medo por invasões. Revelando o real pelo medo, esses dois filmes não espetacularizam o horror inerente à profunda desigualdade social de ambos os países. Mas há horror. Tanto na forma dessas obras, quanto em seus conteúdos.
Ressentidos pelo território: vingança e disputa por causa de uma cerca

\section{Cercas ancestrais e atuais: $O$ som ao redor}

Para Ismail Xavier (2014), o longa de Kleber Mendonça Filho se insere em um conjunto de filmes brasileiros que exploram situações dramáticas protagonizadas pelas figuras do ressentimento. $O$ som ao redor expõe as mazelas sociais e urbanas no seio da família tradicional e patriarcal brasileira, de modo que a temática do ressentimento surge como atualização de um passado mal resolvido disposto em uma estrutura social clara e objetiva. Nesse sentido, a análise de Xavier da presença do passado no presente pode coincidir com a perspectiva de uma maldição que persiste. Uma maldição do mundo arcaico, da aristocracia rural que se perpetua na cidade, tomando as ruas urbanas do Recife na atualidade. Nos diz Xavier que "o paradigma patriarcal e as questões de classe não se articulam [no filme] como relação entre o moderno e uma memória aí contida do passado, mas como presença do passado no presente, como presença hoje de formas de poder e de relações de classe arcaicas. Resulta o travo que encontra seu correlato afetivo no ressentimento" (2014).

À primeira vista, o motivo do ressentimento em 0 som ao redor está encarnado no personagem Clodoaldo e no seu irmão Cláudio, seguranças particulares que invadem uma rua da cidade de Recife, ofertando o serviço de segurança particular. A rua é habitada por famílias de classe-média, sendo que as casas e os edifícios pertencem, em sua maioria, a uma única família, cujo símbolo patriarcal é Seu Francisco, que além de dono dos imóveis é latifundiário. 0 longa se estabelece a partir de histórias aparentemente desconexas entre vizinhos, por vezes familiares, que, no entanto, possuem um fundo temático comum. A menos de dez minutos do fim do filme, os seguranças particulares Clodoaldo e Cláudio são chamados ao apartamento de Seu Francisco. 0 dono da rua propõe um serviço de segurança particular pois
5:: Benjamín Naishtat em entrevista a Directores AV (2014): "Me inspira muito John Carpenter e o cinema de gênero ou de terror político que surgiu nos EUA depois da guerra do Vietnã. Filmes como 0 massacre da serra elétrica (The Texas Chain Saw Massacre, Tobe Hooper, 1974), esse tipo de coisa. Também [Michael] Haneke para a construção da atmosfera, assim como Lucrecia Martel e Carlos Reygadas". 
das fazendas para as ruas (agora privadas) das cidades. Deste modo, tem-se no filme de Mendonça Filho uma representação da figura ressentida como arquétipo do justiceiro, cujo objeto de ressentimento é um indivíduo concreto: o personagem Seu Francisco.

A imagem que abre $O$ som ao redor é uma fotografia em preto e branco de uma cerca, disposta em um prólogo que introduz o passado latifundiário brasileiro ao mesmo tempo em que lança o alicerce do conflito central do longa: a questão da propriedade da terra, do espaço, da cerca -que, não à toa, é a última palavra falada do filme (ver o diálogo transcrito acima)-.

Eloquente ao dispor em paralelo imagens do povo, da terra e do poder sob um sombrio soar de tambores, o prólogo introduz um identificável passado latifundiário brasileiro ao mesmo tempo em que lança o alicerce do conflito central do filme numa dimensão macro, quase que didática, ao expor imagens documentais que pronunciam o embate entre um poder sem rosto (Casa Grande) e os vários rostos do povo, com a terra e a cerca no meio. Clodoaldo, que só surgirá no filme em seus 29 minutos, é uma dessas figuras do povo, sendo que o seu embate está relacionado ao poder da terra: por causa de uma cerca. A primeira imagem que surge no filme, nas fotografias, é a da cerca. A última palavra do filme é “cerca”. E é por trás de uma, justamente, que Clodoaldo surge pela primeira vez em quadro, na imagem de uma câmera de segurança.

Do lado de fora da casa, tio e sobrinho aproximam-se de Clodoaldo e estendem-lhe cordialmente a mão. 0 plano enquadra as personagens lateralmente e a câmera se alinha centralizada exatamente sobre a cerca, que separa os dois parentes do visitante. Este plano conjunto é alternado por planos de campo e contracampo dos de dentro com o de fora. "Meu pai já me dizia: cada um tem o direito de fazer o que quer, no que acredita", diz Clodoaldo para os dois que estão do lado de dentro, na tentativa de convencê-los a adquirir o serviço de segurança que oferece. A alteridade social (donos da terra versus aquele cuja terra foi tomada) apresenta-se, nas imagens e sons do filme de Mendonça Filho, através desta oposição modulada no embate de campo e contracampo utilizado quando Clodoaldo fala com os donos na rua; na imagem reiterada da cerca que tanto parte a terra (como na primeira imagem do filme), quanto separa os corpos dos donos e do desprovido na primeira aparição de Clodoaldo.

No meio das narrativas cotidianas, Clodoaldo e o irmão Cláudio possuem uma motivação de vingança evidenciada apenas no fim do filme. Eles revelam suas verdadeiras intenções na sequência final, "ligando ao prólogo do filme a sua última cena como um retorno do reprimido" (Xavier, 2014). Ressentido e reprimido. Existe um paralelismo entre os dois termos e, não à toa, Xavier os utilizou em um mesmo contexto. Ressentido é o termo do qual Xavier se apropria, dentro de uma tradição que remete a Scheler e a uma fenomenologia do ressentimento, ${ }^{6}$ para se referir a uma temática intensamente presente na cinematografia brasileira, com origens na representação de dramas familiares em conexão com situações de classe e com a vida política, nos quais existe a elaboração e/ou execução de projetos de vingança remoídos. ${ }^{7}$

Já o termo retorno do reprimido, embora não mencionado explicitamente por Xavier, é utilizado pelo teórico inglês Robin Wood (1979) quando este advoga que os monstros, nos filmes de horror, são criaturas que representam partes reprimidas da sociedade e que voltam para assombrar, e se vingar, dos socialmente adequados. Wood inspira-se em considerações tanto da psicologia (Freud), quanto da sociologia (Marx) para elaborar sua teoria a respeito do conceito do repri-
6:: Segundo Ismail Xavier: "No trato com a noção chave, procurare me ater ao nivel do que Scheler define como o da 'fenomenologia do ressentimento', ou seja, a caracterização de um processo de 'auto envenenamentopsicológico' que pode se associar à procura da vingança, que, por impotência, sentimento de inferioridade, se adia e, finalmente, se desloca dos motivos iniciais e pode perder seu alvo, gerando excessiva suscetibilidade, agressividade indeterminada" (Xavier, 2001, p. 81).

7:: Como exemplo dessa elaboração, pode-se citar o longa Cronicamente inviável (Sérgio Bianchi, 2000), que é, nas palavras de Xavier, um filme síntese sobre o ressentimento dos pobres e dos ricos, inaugurando um discurso de autoconsciência da classe-média no cinema brasileiro contemporâneo, que vai ecoar em filmes posteriores, incluindo 0 som ao redor: "0 filme de Bianchi, ao contrário da diatribe conservadora, exibe a ironia ferina de quem tem a lucidez de não poupar o próprio centro do discurso. 0 ressentimento se escancara, vira tema de conversa, atinge a condição de traço fisionômico de uma classe média feita de denegações, infeliz porque está no seu lugar e gostaria de estar fora dele" (Xavier, 2001, p. 95). 
8:: A ideia de "reprimido" ou "recalcado" vem da psicanálise freudiana, contudo, fora apropriada por algumas correntes de esquerda, para se pensar nas dinâmicas sociais. Segundo

Wood: "0 mais significativo desenvolvimento -na crítica filmica, e nas ideias progressivas no geral- das últimas décadas, tem sido claramente, o aumento da confluência de Marx e Freud

ou, mais precisamente, de

tradições de pensamento herdadas deles" $(1979$, p.7)

9:: Personagens como Betânia, Adailson e Dinho, além dos condôminos em reunião e da mulher ao telefone ao buscar

seu carro com Adailson, encenam ressentimentos aparentemente pequenos, mas que resultam em ações violentas diante de um cotidiano no qual a inveja, a amargura e o estresse impregnam a experiência da convivência.

10:: A questão da desapropriação de casas surge também mais adiante, quando, na $\mathrm{TV}$, transmite-se

uma notícia peculiar: um meteoro atingiu um bairro e os moradores devem evacuar o local. mido no cinema de horror. ${ }^{8}$ Ressentido e reprimido, neste contexto, se relacionam com uma perspectiva de alteridade social. Seguindo ideias fundamentadas na psicanálise, e em certo momento apropriadas por uma tradição marxista -na qual podemos pensar em um comportamento/psicologia social-, Wood chama o outro social de reprimido (repressed) pois, em seu corpo, expressam-se desejos, pulsões sexuais e instintos refreados pela dinâmica da sociedade hegemônica. Assim, Wood nos fala a respeito de um retorno do reprimido em épocas de crise e desintegração social e como isso é expresso no cinema através dessas narrativas horríficas, capazes de metaforizar os pesadelos coletivos de uma época ou de uma sociedade. Segundo o autor, os filmes de horror, assim como sua proliferação e popularização, relacionam-se intimamente com momentos de crises e a consequente vontade de superação destas.

0 motivo do ressentimento, contudo, não se encerra apenas na história de Clodoaldo e Cláudio, em 0 som ao redor. Em uma análise mais apurada, descobrimos que tal questão dramática ecoa por muitas personagens do longa-metragem de Mendonça Filho. 0 filme pernambucano apresenta ao espectador, em uma estrutura fragmentada, uma gama de histórias e micro histórias que se agrupam em um mosaico de tipos do cotidiano urbano de uma classe-média recifense, o qual é atravessado, sorrateiramente, pela saga da vingança do oprimido. Identificamos, neste mosaico da vida prosaica urbana, manifestações pontuais do designo do ressentimento que corroboram para a atmosfera de incômodo em relação ao outro social. Este outro pode ser uma vizinha, um familiar, uma madame rica, uma criança, um vendedor de CDs, um cuidador de carros; figuras típicas da vizinhança de uma cidade -são personagens ciumentas, invejosas, que querem ser, querem ter, ou querem exercer um determinado poder-. ${ }^{9}$

\section{Cercas rompidas: Historia del miedo}

Historia del miedo, assim como $O$ som ao redor, constrói um mosaico de situações cotidianas, neste caso foca- das em três núcleos familiares tipificados: a família da periferia que mora em uma pequena casa, a família do centro da cidade que mora em um condomínio vertical e a família do subúrbio rico que mora em um condomínio horizontal. Diferenciando-se essencialmente do título original, a tradução para o português do filme argentino capta precisamente a questão temática que envolve essa geografia de uma metrópole cujos subúrbios são apropriados e desapropriados por pessoas pobres e por pessoas ricas: desenvolvem-se, "bem perto de Buenos Aires" (do centro, da formação mais orgânica ligada às atividades comerciais e industriais), essas bolhas residenciais essencialmente excludentes.

0 primeiro plano do longa-metragem de estreia de Benjamin Naishtat é um aéreo de áreas verdes não urbanizadas. Começam a surgir casas. 0 movimento do helicóptero/da câmera parte de uma região com casas simples e desloca-se até um espaço com mansões e piscinas, local de condomínios ricos. No fim do percurso, o plano captura uma extensa queimada no campo. Sobre a imagem, o som de uma voz metalizada comunica um aviso de despejo junto com o ruído forte do funcionamento das hélices - uma autoridade fala por um alto-falante-. Esse plano aéreo alterna-se com cenas curtas de dentro de um condomínio, com o áudio do helicóptero em continuidade. Moradores reagem aos sons do veículo olhando para o céu. Percebe-se que o subúrbio rico não está distante do subúrbio pobre e o despejo de pessoas de uma ocupação ao redor incomodará aos condôminos (começando pelo anúncio barulhento). ${ }^{10}$

Um acontecimento que se repete confere mistério à trama: as cercas do condomínio estão sendo constantemente violadas e há lixo queimando no limite das mesmas. 0 objeto da cerca é tão presente nesta película quanto em $O$ som ao redor, sendo um dos motivos mais evocados no meio das ações fragmentadas. A questão das queimadas é reiterada e a tensão do filme 
se estabelece na perspectiva dos moradores de dentro do condomínio, receosos com os de fora. Não é revelado com objetividade quem (grupo ou indivíduo) comete as queimadas e as violações das cercas; no entanto, existem fortes indícios que sejam os ocupantes da área vizinha que estão sendo despejados. Aqui, aqueles que estão sendo expulsos da ocupação rompem a cerca do condomínio de modo que se instaura, em determinado momento da película, uma espécie de pânico pela invasão. Como ocorre na história mais proeminente de $O$ som ao redor, a cerca simboliza a disputa territorial. Muito embora não há resolução clara para as queimadas e para os rompimentos da cerca, na construção audiovisual do filme há alguns indícios de uma possível ligação da personagem Pola, garoto que transita entre a periferia pobre (onde mora) e a rica (onde trabalha).

Na montagem do filme, por exemplo, alternam-se dentro de uma mesma sequência uma cena em que Pola fica visivelmente transtornado enquanto janta (ao ponto de arrastar todos os pratos da mesa para o chão), com ele saindo de moto por uma estrada do subúrbio, seguida de uma cena na qual ocorre um súbito corte de luz dentro do condomínio. Os moradores ficam apreensivos e, no fim da sequência, vemos que Pola está não só dentro do condomínio, mas dentro de uma das casas. Não se esclarece o motivo da raiva de Pola, muito menos se ele teve envolvimento com os cortes de cercas e de luz, mas a causalidade na montagem promove um desencadeamento narrativo, ainda que encoberto de ambiguidade, que nos entrega uma pista de envolvimento de Pola com o motivo de uma suposta invasão -ou é do funcionário que os condôminos possuem medo, por ele ser o outro social, ainda que em nada envolvido com os estranhos acontecimentos-. E o filme nos concede esse ponto de vista. Já na trilha sonora, Pola é o único personagem que possui um tema musical (uma sonoridade sintetizada misteriosa que lembra sons de filmes clássicos de ficção científica), o que afırma, se não um protagonismo, ao menos um destaque. Vale lembrar que é seu rosto que estampa um dos cartazes do longa-metragem, e que o filme se encerra com essa personagem sendo entrevistada.

Pola, mais do que trazer uma resposta a um filme de suspense, emerge como concretização simbólica do intenso medo dos que estão dentro do condomínio, dos que possuem. Medo do quê? Da vingança do oprimido, do ressentimento, do desprovido? Pola anda sozinho, curvado, veste roupas escuras. No início da película ele está em uma das ruas do condomínio de luxo e destoa da claridade e simetria que o rodeia. Jardins com grama aparada e árvores podadas, tudo muito verde claro -a imagem seria toda luminosa, não fosse por Pola que, além de usar cores escuras, tem sol atrás de si, o que imprime uma figura coberta por sombras-.

Um pouco depois, a câmera está no banco de trás (um over the shoulder) de um carro de segurança e vemos a rua privada à frente. Enquanto o segurança sai do veículo para averiguar uma moradia, temos um super-close lateral de Pola olhando para fora do carro. 0 close ocorre em continuidade com um plano de uma garota vista pelo vidro. Ela está em plano médio, centralizada, bem iluminada pelo sol e em ligeiro contra-plongée, simulando uma subjetiva do olhar de Pola. Ela vira o seu rosto em direção ao carro, onde Pola está sentado. Volta o super-close de Pola, que abaixa seu rosto, desviando o olhar.

Essa cena (no início do filme) revela um aspecto importante de Pola: um deles é a propriedade do olhar que contempla (possivelmente desejoso) e, ao mesmo tempo, desvia. A garota está em um patamar superior: está em pé, cheia de claridade e filmada em contra- plongée. Pola não desvia o olhar do segurança que o concede uma carona, mas da moradora, sim. Esse jogo de olhar da cena, que dura segundos, traduz uma alteridade entre o funcionário sombrio e a moradora iluminada de forma sutil e cinematográfica. 


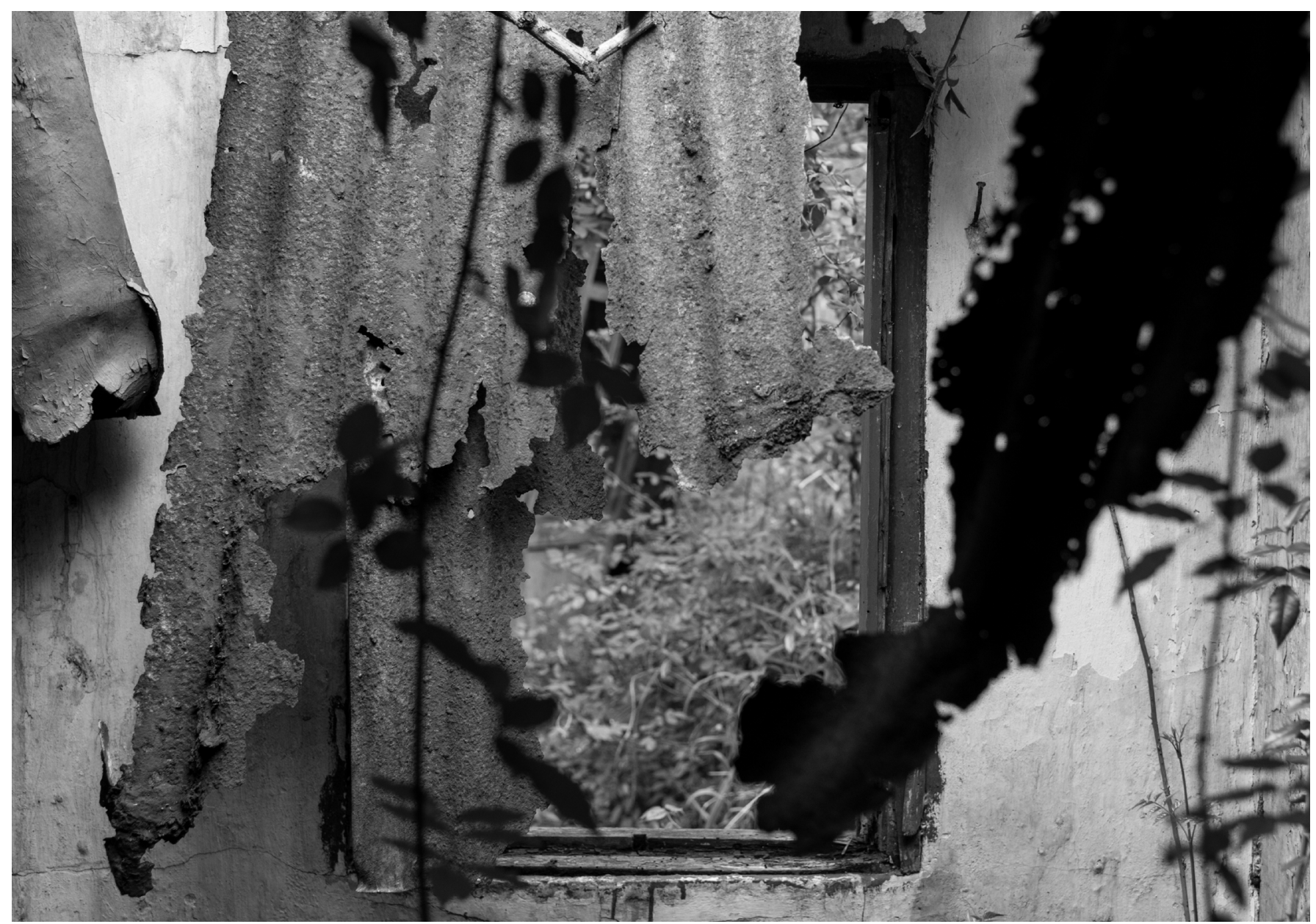

Foto: Ignacio Sánchez

Como veremos ao longo do filme, o jovem é uma figura extremamente silenciosa e misteriosa. Em vinte minutos de filme, por exemplo, Pola está diante de um trecho violado de cerca, e ao seu lado estão um morador e o segurança. 0 morador, senhor já com mais de 40 anos, com óculos, blusa polo, relógio de pulso, questiona o jovem de fronte suada e boné cobrindo a face: "Cortaram a cerca, você viu? É muito perigoso". 0 rapaz, timidamente, assente com a cabeça, voltando sua face para baixo. Personagem enigmática, Pola se destaca em sua ambiguidade sombria em comparação com outras personagens mais tipificadas e superficiais, como os condôminos, por exemplo.
Frequentemente enquadrado em closes e super-closes, Pola transmite sua insatisfação no seu silêncio, no seu corpo tenso e recuado, no seu olhar ofendido em algumas situações de humilhação cotidiana. 0 ressentimento, aqui, pressupõe um misto de submissão e desejo, ambos velados na face sombria desta personagem. Pola, assim, é a figura principal de alteridade, que encarna um possível ressentimento em seu corpo, temido pelos de dentro. Todavia, assim como a história de Clodoaldo e seu irmão, no filme argentino os momentos de Pola se alternam com banalidades corriqueiras recheadas de apreensões. Apesar de transitar entre os espaços não nos é revelado se Pola tem alguma questão territorial, como ocorre de forma mais evidente em $O$ som ao redor. 
Muito embora não trace o paralelo com o passado da Argentina, como o longa pernambucano faz com as raízes da aristocracia rural e patriarcal do Brasil, Historia del miedo, ao tensionar os espaços da periferia pobre e da periferia rica, põe em pauta um conflito estrutural latino-americano: quem é dono da terra. Ou melhor: de que lado da cerca você está? Não à toa, Naishtat assume o intuito de duplo significado do título original Historia del miedo - ao mostrar a superfície das relações cotidianas, faz emergir a história do medo que constrói e segrega, ${ }^{11}$ desde muito, os territórios de moradia e convivência na Argentina-. Estamos diante, nos dois filmes, de duas Histórias sobre cercas violentamente tomadas.

0 objeto da cerca é fundamental, visualmente concreto e narrativamente relevante em ambas as obras analisadas. Como motivo primordial das ações, ela separa, em $O$ som ao redor, o ressentido do que originalmente lhe pertencia - a terra-, sendo razão da disputa histórica resgatada em um presente urbano e complexo. Já em Historia del miedo, a cerca violada impõe o motivo de temor pelos de dentro. Neste caso, ergue-se uma atmosfera de apreensão sem respaldo num desfecho causal. Mas os sinais são claros: a situação vai explodir e queimadas, fogos de artifício e até mesmo um meteoro que surge inesperadamente anunciam uma catástrofe. 0 ressentimento brota, nos dois filmes, de um desejo ao acesso. No caso das tramas principais, esse acesso desejado é em relação à terra e ao espaço, é fruto do território cisado.

\section{Narrativas e territórios}

fragmentados pelo medo

Debruçando-se sobre a relação que os filmes estabelecem com a tradição do horror, encontramos na esfera temática do ressentimento e do motivo temático do passado no presente, levantada por Xavier diante do longa-metragem pernambucano, uma possível ligação com o que foi teorizado por Robin Wood (1979) sobre filmes norte-americanos de horror. Apropriando-se do amplo conceito de alteridade social, Wood aproxima a figura do monstro de filmes de horror clássicos norte-americanos, como por exemplo o monstro de Frankenstein (James Whale, 1931), com a noção de outro social. Para o teórico, as histórias de horror trariam, ainda que inconscientemente para o cineasta e a equipe, sintomas e pistas de uma sociedade tradicional, patriarcal e normativa sob ameaça, sendo que as figuras monstruosas expressariam as parcelas reprimidas desse sistema social dominante. 0 proletariado, minorias étnicas, mulheres, estrangeiros e até crianças teriam suas pulsões contraculturais expressas sob a fantasia e o horror de seres que ameaçam o status quo. Para Wood, a fórmula básica para os filmes de horror tradicionais consiste na normalidade ${ }^{12}$ posta em perigo por monstros -seres estranhos que assumem diferentes aspectos de acordo com a época em que se inserem-. 0 fundamental, nesse sentido, é a presença constante da ameaça ao normatizado.

Embora de vocação realista, os dois longas-metragens aqui analisados articulam as suas atmosferas do medo sobre uma trama na qual figuras ressentidas pelo território perdido -Clodoaldo e Cláudio ou Pola- surgem como dispositivos de ameaça para as fragilidades sociais do meio em que convivem. Como monstros nos filmes de horror, que, segundo Wood, ameaçam o establishment, os aqui reprimidos e ressentidos dão vazão para a atemorização dos outros com quem convivem (os patrões, os donos de territórios) e ameaçam romper a normalidade instaurada. ${ }^{13}$

Os dois filmes aqui analisados explicitam, de forma paralela e utilizando as mesmas referências, as ruínas de um momento específico cujo medo do outro, da invasão, da vingança e da ruptura torna-se o horror, e de onde algumas figuras do ressentimento emergem,
11:: A cineasta argentina Lucrecia Martel possui um curta-metragem documental sobre os gigantescos condomínios de Buenos Aires chamado La ciudad que huye (2006). 0 filme revela alguns aspectos peculiares destes tipos de aglomerados, como suas largas extensões e 0 aspecto de fortaleza.

12:: "I use normality here in a strictly nonevaluative sense, to mean simply conformity to the dominant social norms; one must firmly resist the common tendency to treat the word as if it were more or less synonymous with health"

(Wood, 1979, p. 16).

13:: Natalia Christofoletti Barrenha, ao analisar o filme Historia del miedo, também leva em conta a relação com o horror pela perspectiva do monstro. Ver Christofoletti Barrenha (2019). 
14:: Em ambos os filmes, meninos são "capturados", como se fossem feras ou bichos. Logo no início do longa argentino, dentro de uma lanchonete, um jovem se coloca de quatro no chão, ao que um segurança o "acalma"

e o imobiliza. Já no filme brasileiro, um menino negro anda pelos telhados e sobre as copas de árvores até ser descoberto pelos vigias da rua. Eles o derrubam dos galhos de uma árvore e dão uma surra nele. Para uma abordagem mais aprofundada sobre a animalização desses corpos ver Sales Rocha Santos (2018).

15:: Devido a

enquadramentos, iluminação e expressão facial de algumas personagens, ou mesmo pelo paralelo com os zumbis que Naishtat realiza em determinado momento de seu

filme -incluindo, no lugar desse monstro clássico, um homem nu, provável vítima de um incêndio-.

16:: "A literatura gótica, contudo, possui, desde sua origem, duas tradições opositivas: a linhagem

de Horace Walpole, a do horror sobrenatural, que se contrapunha ao racionalismo e ao realismo que começavam a se impor nos romances do final do século XVIII, e a linhagem de Ann Radcliffe, em que o elemento sobrenatural é subjugado pela razão, e os atos humanos são a causa dos verdadeiros horrores"

(Colavitto, 2008, p. 44 citado em França, 2015, p. 133). tanto no Brasil, quanto na Argentina contemporâneos. Figuras do ressentido socialmente são ora animalizadas, ${ }^{14}$ ora monstrificadas. ${ }^{15}$

0 medo muito anunciado, porém nunca concretizado, frustrado, também nos aproxima de uma tradição específica do horror: o gótico narrativo. Os enredos de histórias góticas ligados a uma vertente radcliffiana,${ }^{16}$ no geral, prezam por densas ambientações e climatizações em lugar de conflitos explícitos. Nesse sentido, o estilo gótico seria tão operacional quanto o horror fílmico para o entendimento da atmosfera do medo em ambos os longas. De acordo com Edmund Burke (1958), a história gótica por excelência seria percorrida por vias desiguais de continuidade e descontinuidade, de modo a evitar, sobretudo, os conflitos e desfechos imediatos. Assim, o suspense é criado por um elemento formal que é o da descontinuidade. Nesse sentido, a fragmentação da história em subenredos, como ressalta Daniel Serravalle de Sá, ao garantir o adiamento do clímax narrativo, contribui para a articulação do suspense e do medo no enredo:

$\mathrm{Na}$ literatura gótica, isso se formaliza na fragmentação da história em diferentes linhas narrativas, as quais contribuem para a complexidade do enredo. A técnica consiste em dilatar a narrativa em inúmeros episódios, intercalando subenredos e abrindo diversas frentes de antecipação. 0 resultado é um efeito de suspense que prende a atenção do leitor. Enquanto a representação de conflitos é postergada, o clímax narrativo é adiado para outro momento (Serravalle de Sá, 2010, p. 88).
Deste modo, a técnica narrativa de articular vários subenredos numa mesma trama, suspendendo-os e adiando o clímax, é elemento que intensifica as tensões pré-existentes na medida em que não se foca num conflito dramático central e único, de resolução rápida. Nos dois filmes em análise, essa fragmentação dos enredos, elemento central do repertório da imaginação horrífica, adiam os conflitos das cercas, de modo que "circulamos" pelos arredores do conflito essencial, sempre adiado, enquanto assistimos como algumas figuras sociais agem e reagem naqueles ambientes.

As atmosferas do medo em $O$ som ao redor e em Historia del miedo se configuram a partir de tramas cujos enredos fragmentados possuem um motivo temático, no qual figuras do ressentimento pela terra e pelo espaço dividido pelas cercas assombram concreta e psicologicamente os donos da terra, ou melhor, aqueles que têm medo de perdê-la. A cisão da terra e a cisão narrativa, ambas, originam o medo, tanto nas personagens quanto na sensação de suspense que a narrativa gera ao expectador.

\section{Referências}

Calil, R. (2015, 08 de março). Crítica: Tensão de longa argentino faz lembrar a de 0 som ao redor. Folha de São Paulo. Recuperado de https://www1.folha.uol.com.br/ ilustrada/2015/03/1599151-critica-tensao-de-longa-argentino-faz-lembrar-a-de-o-som-ao-redor.shtml

Christofoletti Barrenha, N. (2019). Espaços em conflito. Ensaios sobre a cidade no cinema argentino contemporâneo. São Paulo, Brasil: Intermeios. 
Directores AV (2014, 09 de setembro). Directores - Benjamin Naishtat. Recuperado de https://www.youtube.com/ watch?v=MAxam5ifndg $\mathrm{t} t=75 \mathrm{~s}$

Burke, E. (1958). A Philosophical Inquiry Into the Origins of Our Ideas About the Sublime and the Beautiful. Londres, Reino Unido: Routledge \&t Kegan Paul.

Enelset CINE (2014, 20 de maio). Entrevista a Benjamín Naishtat. Recuperado de https://www.youtube.com/ watch? $v=1 \mathrm{nzNJD}$ oumMM\&t $=56 \mathrm{~s}$

Ferreira, P. H. (2014, 23 de setembro). Bem perto de Buenos Aires (Historia del miedo), de Benjamin Naishtat (Argentina, 2014). Revista Cinética. Recuperado de http:// revistacinetica.com.br/home/bem-perto-de-buenos-aires-historia-del-miedo-de-benjamin-naishtat-argentina-2014/

França, J. (2015). As sombras do real: A visão de mundo gótica e as poéticas realistas. Em A. Chiara e F. C. D. Rocha (Eds.), Literatura brasileira em foco VI: Em torno dos realismos (pp. 133-146). Rio de Janeiro, Brasil: Casa Doze.

Mendonça, L. (2015, 15 de fevereiro). Kleber Mendonça FiIho: "Sou fascinado pela agressão que não é óbvia". $\dot{A}$ pala de Walsh. Recuperado de http://www.apaladewalsh. com/2015/02/kleber-mendonca-filho-sou-fascinado-pela-agressao-que-nao-e-obvial

Punter, D. (1980). The Literature of Terror: A History of Gothic Fiction from 1765 to the Presente Day. Londres, Reino Unido: Longman.

Sales Rocha Santos, F. (2018). Atmosferas do medo: Filmes brasileiros e argentinos do início do século XXI. Dissertação de Mestrado em Meios e Processos Audiovisuais. São Paulo: Escola de Comunicações e Artes da Universidade de São Paulo - USP. Recuperado de http://www.teses.usp. br/teses/disponiveis/27/27161/tde-26122018-170428/ pt-br.php
Serravalle de Sá, D. (2010). Gótico tropical: O sublime e o demoníaco em 0 Guarani. Salvador, Brasil: EdUFBA.

Souto, M. (2012). 0 que teme a classe média? Trabalhar cansa e o horror no cinema brasileiro contemporâneo. Contracampo, 25, 43-60. Recuperado de http://periodicos.uff. $\mathrm{br} /$ contracampo/article/view/17270/10908

Xavier, I. (2001). A figura do ressentimento no cinema brasileiro dos anos 90. Em J. Gatti, F. Ramos, A. Catani e M. D. Mourão (Orgs.), Estudos de cinema 2000 - Socine (pp. 77-97). Porto Alegre, Brasil: Editora Sulina.

Xavier, I. (2002). 0 concerto do ressentimento nacional. Sinopse, IV(8), 35-37. Recuperado de http://www.educadores. diaadia.pr.gov.br/arquivos/File/2010/veiculos_de_comunicacao/SIN/SIN08/SIN08_08.PDF

Xavier, I. (2006). Corrosão social, pragmatismo e ressentimento: Vozes dissonantes no cinema brasileiro de resultados. Novos Estudos Cebrap, 75, 139-155. Recuperado de http://www.fflch.usp.br/centrodametropole/antigo/v1/ pdf/2007/ismail_corrosao_social.pdf

Xavier, I. (2014). 0 cinema ao redor. Anais digitais do XVIII Encontro Socine. Recuperado de https://associado.socine. org.br/anais/2014/14335/ismail_xavier/o_cinema_ao_redor

Wood, R. (1979). The American Nightmare: Essays on the Horror Film. Ann Arbor, MI: University of Michigan Press.

Filmes

Mendonça Filho, K. (Diretor). (2013). 0 som ao redor [Filme]. Brasil: CinemaScópio.

Naishtat, B. (Diretor). (2014). Historia del miedo [Filme]. Argentina, França, Uruguai, Alemanha, Catar: Rei Cine, Ecce Films, Mutante Cine e Vitakuben. 